\title{
Dynamics of cytokine profile indexes in children with first diagnosed pulmonary tuberculosis in the course of antimycobacterial therapy
}

\author{
0. M. Raznatovska, Yu. V. Mironchuk
}

Zaporizhzhia State Medical University, Ukraine

Key words: cytokines, children, tuberculosis, treatment.

Zaporozhye medical journa 2018; 20 (2), 206-210

DOl:

10.14739/2310-1210 2018.2.125171

E-mail: raxnatovskaya@ gmail.com
Antimycobacterial therapy is the main method of tuberculosis treatment. But some antimycobacterial medications have an unfavorable influence on the immune system and this fact significantly decreases efficiency of treatment and requires an additional pathogenetic immunocorrection.

The aim of the work - to research dynamics of cytokine profile indexes in blood serum of children with first diagnosed pulmonary tuberculosis in the course of antimycobacterial therapy depending on specific process prevalence and to assess efficiency of antimycobacterial therapy after the basic course of treatment completion for further immunocorrecting therapy development.

Materials and methods. Study of cytokine profile indexes was performed in 28 children with first diagnosed pulmonary tuberculosis from 1 to 16 years old (the average age was $9.2 \pm 1.1$ years). Depending on the specific process prevalence children with first diagnosed pulmonary tuberculosis were divided into two groups: the first group included 17 persons with a disseminated process and the second group included 11 persons with an isolated process. The comparison group included 30 healthy children. Comparison groups were age-matched and gender-matched. Cytokine profile indexes were studied by means of IL-2, IL-6, IL-4, IL-10 levels detection in blood serum through enzyme-linked immunosorbent assay using immunoenzymometric reader Sirio S and a set "Bender MedSystems GmbH" (Austria), (pg/ml). Dynamics of cytokine indexes was studied at the beginning of the antimycobacterial therapy intensive phase, on completion of the antimycobacterial therapy intensive phase ( 2 months after treatment) and on completion of the antimycobacterial therapy maintenance phase (6 months after treatment). Parents of all sick children signed patient's written informed consent for participation in this study. Results of this work were processed by the modern methods of analysis with the help of a personal computer and the statistical package of the licensed software program Statistica ${ }^{\circledR}$ for Windows 6.0 (StatSoft Inc., № AXXR712 D833214FAN5).

Results. A significantly high level of pro-inflammatory cytokine IL-2 characterized Th1-type of cellular immune response high activity in children with first diagnosed pulmonary disseminated tuberculosis throughout the entire course of antimycobacterial therapy. And significantly stably low levels of anti-inflammatory cytokines IL-4 and IL-10 indicated insufficiency of anti-inflammatory response throughout the entire course of antimycobacterial therapy. Calculation of cytokine indexes (and namely the IL-2/ IL-10 ratio) has conformed that there was a disbalance between pro-inflammatory and anti-inflammatory cytokines towards pro-inflammatory cytokines with predominance of Th1-type cellular immune response which lasted during the entire course of antimycobacterial therapy and tended to decline on its completion. Even though that in the course of antimycobacterial therapy in children with bacterioexcretion this process stopped, average duration of in-patient treatment was 9-10 months and that was 3 months longer than standard treatment of patients with first diagnosed pulmonary tuberculosis. The warning sign is also that among children with disseminated tuberculosis there were 3 cases (17.6\%) of multidrug-resistant tuberculosis in the course of treatment and in case with 1 child (5.9\%) lung destruction was persisted on the treatment completion.

Conclusions. Children with first diagnosed pulmonary tuberculosis (regardless of the specific process prevalence) had a high activity of Th1-type cellular immune response against the background of an extremely decreased activity of Th2-type cellular immune response throughout the entire course of antimycobacterial therapy. This fact indicates insufficiency of anti-inflammatory response. At the same time all children had a pronounced disbalance between pro-inflammatory and antiinflammatory cytokines towards pro-inflammatory ones on completion of the treatment basic course. These changes may contribute to the specific process progression as well as early recurrences of the disease.
Киючові слова: цитокіни, діти, туберкульоз, мікування.

Запорізький медичний журнал. - 2018. T. 20, № 2(107). C. $206-210$

\section{Аинаміка показників цитокінового профілю в дітей, які хворі на вперше діагностований туберкульоз мегень, у процесі застосування антимікобактеріальної терапії}

\section{О. М. Разнатовська, Ю. В. Мирончук}

Антимікобактеріальна терапія - основний метод лікування туберкульозу. Деякі антимікобактеріальні препарати мають несприятливий вплив на стан імунної системи, що істотно знижує ефективність лікування хворих, потребує додаткової патогенетичної іммунокорекції.

Мета роботи - дослідити динаміку показників цитокінового профрілю в сироватці крові дітей, які хворі на вперше діагностований туберкульоз легень, у процесі застосування антимікобактеріальної терапії залежно від поширеності специфічного процесу; оцінити ефективність антимікобактеріальної терапії після завершення основного курсу лікування для розроблення раціонально спрямованої імунокоригувальної терапії.

Матеріали та методи. Показники цитокінового профілю вивчили у 28 дітей, які хворі на вперше діагностований туберкульоз легень, віком від 1 до 16 років (середній вік - 9,2 \pm 1,1 року). Залежно від поширеності специффічного процесу дітей поділили на 2 групи: група 1 - 17 осіб із поширеним процесом, група 2 - 11 осіб з обмеженим процесом. До групи порівняння увійшли 30 здорових дітей. За віком і статтю групи були зіставні. Показники цитокінового профрілю вивчали шляхом дослідження рівнів IL-2, IL-6, IL-4, IL-10 у сироватці крові методом твердофазного імуноферментного аналізу на приладі імуноферментний рідер Sirio $S$ із застосуванням набору «Bender MedSystems GmbH» (Austria), результати наведені у пкг/мл. Динаміку показників цитокінів досліджували на початку інтенсивної фази антимікобактеріальної 
терапії, після її завершення (через 2 місяці лікування), а також після підтримувальної фази антимікобактеріальної терапії (через 6 місяців лікування). Батьки всіх хворих дітей підписали інформовану письмову згоду пацієнта на участь у дослідженні. Результати опрацьовані сучасними методами аналізу на персональному комп'ютері з використанням статистичного пакета ліцензійної програми Statistica ${ }^{\circledR}$ for Windows 6.0 (StatSoft Inc., № AXXR712 D833214FAN5).

Результати. У дітей, які хворі на вперше діагностований туберкульоз легень із поширеним процесом, протягом усього курсу антимікобактеріальної терапії вірогідно високий рівень прозапального цитокіну IL-2 свідчив про високу активність Th1-типу клітинної відповіді імунітету. Вірогідно стабільно знижені рівні протизапальних цитокінів IL-4 та IL-10 вказували на недостатність протизапальної відповіді протягом усього курсу антимікобактеріальної терапії. Розрахунок цитокінових коефріцієнтів, як-от IL-2/IL-10, підтвердив дисбаланс про- та протизапальних цитокінів у бік прозапальних цитокінів із переважанням Th1-типу клітинної відповіді, який зберігався протягом усього курсу антимікобактеріальної терапії та мав тенденцію до зниження після його завершення. У всіх дітей із бактеріовиділенням протягом антимікобактеріальної терапії визначали його припинення. Середня тривалість стаціонарного лікування становила 9-10 місяців, що перевищує стандарти лікування хворих на вперше діагностований туберкульоз легень на 3 місяці. Серед дітей із поширеним туберкульозом у процесі лікування зареєстровано 3 випадки (17,6 \%) мультирезистентного туберкульозу, а в 1 дитини (5,9 \%) деструкції в легенях після лікування не загоїлись.

Висновки. У дітей, які хворі на вперше діагностований туберкульоз легень, незалежно від поширеності специфічного процесу протягом усього курсу антимікобактеріальної терапії визначається висока активність Тһ1-типу клітинної відповіді імунітету на тлі різко зниженої активності Th2-типу клітинної відповіді, що вказує на недостатність протизапальної відповіді. Після основного курсу лікування в усіх дітей зберігається виражений дисбаланс про- та протизапальних цитокінів у бік прозапальних цитокінів. Такі зміни можуть спричиняти прогресування специфічного процесу, виникнення ранніх рецидивів захворювання.

\section{Аинамика показателей цитокинового профияя у детей, больных впервые диагностированным туберкулезом легких, в процессе применения антимикобактериальной терапии}

\section{Е. Н. Разнатовская, Ю. В. Мирончук}

Антимикобактериальная терапия - основной метод лечения туберкулеза. Некоторые антимикобактериальные препараты оказывают неблагоприятное влияние на состояние иммунной системы, что значительно снижает эффеективность лечения больных и требует дополнительной патогенетической иммунокоррекции.

Цель работы - исследовать динамику показателей цитокинового профиля в сыворотке крови детей, больных впервые диагностированным туберкулезом легких, в процессе применения антимикобактериальной терапии в зависимости от распространенности специфического процесса; оценить эффективность антимикобактериальной терапии по завершению основного курса лечения для дальнейшей разработки рационально направленной иммунокоррегирующей терапии.

Материалы и методы. Изучение показателей цитокинового профиля проведено у 28 детей, больных впервые диагностированным туберкулезом легких, в возрасте от 1 до 16 лет (средний возраст - 9,2 \pm 1,1 года). В зависимости от распространенности специфического процесса детей разделили на 2 группы: группу 1 составили 17 человек с распространенным процессом, группу 2 - 11 человек с ограниченным процессом. В группу сравнения вошли 30 здоровых детей. По возрасту и полу группы сравнения сопоставимы. Показатели цитокинового профиля изучали путем исследования уровней IL-2, IL-6, IL-4, IL-10 в сыворотке крови методом твердофазного иммуноферментного анализа на приборе иммуноферментный ридер Sirio S с применением набора «Bender MedSystems GmbH» (Austria), результаты представлены в пг/мл. Исследование динамики показателей цитокинов проводили в начале интенсивной фазы антимикобактериальной терапии, по ее завершению (через 2 месяца лечения), по завершению поддерживающей фазы антимикобактериальной терапии (через 6 месяцев лечения). Родители всех больных детей подписали информированное письменное согласие пациента на участие в исследовании. Результаты обработаны современными методами анализа на персональном компьютере с использованием статистического пакета лицензионной программы Statistica ${ }^{\circledR}$ for Windows 6.0 (StatSoft Inc., № AXXR712 D833214FAN5).

Результаты. У детей, больных впервые диагностированным туберкулезом легких с распространенным процессом, на протяжении всего курса антимикобактериальной терапии достоверно высокий уровень провоспалительных цитокинов IL-2 свидетельствовал о высокой активности Th1-типа клеточного ответа иммунитета. Достоверно стабильно сниженные уровни противовоспалительных цитокинов IL-4 и IL-10 указывали на недостаточность противовоспалительного ответа в течение всего курса антимикобактериальной терапии. Расчет цитокиновых коэффрициентов, а именно IL-2/ IL-10, подтвердил дисбаланс про- и противовоспалительных цитокинов в сторону провоспалительных цитокинов C преобладанием Th1-типа клеточного ответа, который сохранялся на протяжении всего курса антимикобактериальной терапии и имел тенденцию к снижению по его завершению. У всех детей с бактериовыделением в течение антимикобактериальной терапии отмечено его прекращение. Средняя продолжительность стационарного лечения составила 9-10 месяцев, что превышает стандарты лечения больных впервые диагностированным туберкулезом легких на 3 месяца. Среди детей с распространенным туберкулезом в процессе лечения зарегистрированы 3 случая (17,6 \%) мультирезистентного туберкулеза, а у 1 ребенка (5,9 \%) деструкции в легких по завершению лечения не зажили.

Выводы. У детей, больных впервые диагностированным туберкулезом легких, независимо от распространенности специфического процесса на протяжении всего курса антимикобактериальной терапии определяется высокая активность Th1-типа клеточного ответа иммунитета на фоне резко пониженной активности Th2-типа клеточного ответа, что указывает на недостаточность противовоспалительного ответа. По завершению основного курса лечения у всех детей сохраняется выраженный дисбаланс про- и противовоспалительных цитокинов в сторону провоспалительных цитокинов. Такие изменения могут способствовать прогрессированию специфического процесса и возникновению ранних рецидивов заболевания.
Ключевые слова: цитокины, Аети, туберкулез, мечение.

Запорожский медицинский журнал. - 2018. T. 20, № 2(107). C. 206-210 
Particular attention is currently being paid to the epidemiological situation of tuberculosis in children [1]. In case with this age category there are certain changes in organism immunologic responsiveness which are quite different from those of adult population [2,3]. The level of immune system changes in organism has a direct influence on activity of pulmonary affection and it promotes increase in Mycobacterium tuberculosis population [4]. And at the same time immunological deficiency development may be caused by direct toxic effect of Mycobacterium tuberculosis. It is not improbable that increase in Mycobacterium tuberculosis drug resistance types in the process of antimycobacterial therapy (AMBT) is a consequence of immune system weakening.

Data presented by many researches have proved a pathogenic role of cytokines and their disbalance in tuberculosis cases but these data are quite diverse $[5,6]$. Cytokines (endogenous mediators) regulate intensity and duration of immune inflammatory response [3]. Cytokines formation may be stimulated by various irritants. The most cytokines are the key factors regulating inflammatory response and acute phase response of the organism; they may also cause immunopathological effect on cells and tissues [7, 8]. While also a normal immune response development is impossible without cytokines [9].

Certainly, antimycobacterial therapy is the main method of tuberculosis treatment. But some antimycobacterial medications have an unfavorable influence on the immune system and this fact significantly decreases treatment efficiency and requires an additional pathogenetic immunocorrection.

\section{The aim of the work}

To research dynamics of cytokine profile indexes in blood serum of children with first diagnosed pulmonary tuberculosis in the course of antimycobacterial therapy depending on specific process prevalence and to assess efficiency of antimycobacterial therapy after the basic course of treatment completion for further immunocorrecting therapy development.

\section{Materials and methods}

Study of cytokine profile indexes was performed in 28 children with FDPTB from 1 to 16 years old (the average age was $9.2 \pm 1.1$ years) who were at the pediatric inpatient clinical part of Phthisiology and Pulmonology Department of Zaporizhzhia State Medical University at the municipal institution "Zaporizhzhia Regional Antituberculosis Clinical Dispensary". Depending on the specific process prevalence children with first diagnosed pulmonary tuberculosis were divided into two groups: the first group included 17 persons with a disseminated process and the second group included
11 persons with an isolated process. The comparison group included 30 healthy children. Comparison groups were agematched and gender-matched.

Cytokine profile indexes were studied by means of IL2, IL-6, IL-4, IL-10 levels detection in blood serum through enzyme-linked immunosorbent assay using immunoenzymometric reader Sirio $S$ and a set "Bender MedSystems GmbH" (Austria), (pg/ml).

Dynamics of cytokine indexes was studied at the beginning of the AMBT intensive phase (IPh), on completion of the IPh AMBT (2 months after treatment) and on completion of the maintenance phase (MPh) AMBT (6 months after treatment). Parents of all sick children signed patient's written informed consent for participation in this study.

Results of this study were processed by the modern methods of analysis with the help of a personal computer and the statistical package of the licensed software program Statistica ${ }^{\circledR}$ for Windows 6.0 (StatSoft Inc., № AXXR712D833214FAN5). Normality of distribution of quantitative indices was analyzed using the Shapiro-Wilks test. Descriptive statistics was presented in form of a median with interquartile range $-\mathrm{Me}\left[\mathrm{Q}_{25} ; \mathrm{Q}_{75}\right]$, as far as the matter was about the parameter which differ from the normal one. Significance of differences between the compared values was defined with a help of Mann-Whitney test. All tests were two-sided. A statistically important difference was defined at the level of $P<0.05$.

\section{Results and discussion}

Through studies of cytokine indexes in blood serum of children with disseminated FDPTB in the entire course of AMBT (Table 1) the following changes were defined. The level of pro-inflammatory cytokine IL-2 was significantly higher than in the comparison group in the course of AMBT with a tendency to slight decrease on the MPh AMBT completion: $1.18(0.94 ; 1.60) \mathrm{pg} / \mathrm{ml}, 1.06(0.64 ; 1.30) \mathrm{pg} / \mathrm{ml}$ and 0.84 $(0.46 ; 1.46) \mathrm{pg} / \mathrm{ml}$ as compared with $0.30(0.24 ; 0.35) \mathrm{pg} / \mathrm{ml}$ $(P<0.05)$. Levels of anti-inflammatory cytokines IL-4 and $\mathrm{IL}-10$ in the entire course of AMBT were significantly stably low: IL-4 was on the average 3 times lower $(0.52(0.28 ; 0.68)$ $\mathrm{pg} / \mathrm{ml}, 0.58(0.52 ; 0.72) \mathrm{pg} / \mathrm{ml}$ and $0.60(0.50 ; 0.72) \mathrm{pg} / \mathrm{ml}$ as compared with $1.74(1.54 ; 1.94) \mathrm{pg} / \mathrm{ml} ; P<0.05)$ and IL-10 was 5 times lower $(0.60(0.48 ; 1.56) \mathrm{pg} / \mathrm{ml}$ on the IPhAMBT completion and $0.62(0.30 ; 1.26) \mathrm{pg} / \mathrm{ml}$ on the MPh AMBT completion $(P<0.05)$. The level of IL-6 during the course of treatment was significantly low.

Cytokine indexes IL-2/IL-10 relative units and IL-6/ $\mathrm{IL}-10$ relative units were indicative of the pro-inflammatory cytokines to anti-inflammatory cytokines ratio (Fig. 1). So, in children with FDPTB with disseminated tuberculosis the level of IL-2/IL-10 index was high as related to that one

Table 1. Dynamics of cytokine indexes in blood serum of children with disseminated FDPTB in the course of AMBT Me $\left[Q_{25} ; Q_{75}\right]$

\begin{tabular}{lllll}
\hline Cytokines, $\mathrm{pg} / \mathrm{ml}$ & $\begin{array}{l}\text { Comparison group } \\
(\mathbf{n}=\mathbf{3 0})\end{array}$ & Main group $(\mathbf{n}=17)$ & \\
\cline { 3 - 5 } & & At the beginning of IPh AMBT & On the IPh AMBT completion & On the MPh AMBT completion \\
\hline IL-6 & $1.58(1.45 ; 1.78)$ & $0.12(0.10 ; 0.30)^{*}$ & $0.12(0.10 ; 0.16)^{*}$ & $0.08(0.08 ; 0.12)$ \\
IL-4 & $1.74(1.54 ; 1.94)$ & $0.52(0.28 ; 0.68)^{*}$ & $0.58(0.52 ; 0.72)^{*}$ & $0.60(0.50 ; 0.72)^{*}$ \\
IL-2 & $0.30(0.24 ; 0.35)$ & $1.18(0.94 ; 1.60)^{*}$ & $1.06(0.64 ; 1.30)^{*}$ & $0.84(0.46 ; 1.46)^{*}$ \\
IL-10 & $3.47(2.88 ; 3.68)$ & $0.82(0.48 ; 2.26)$ & $0.60(0.48 ; 1.56)^{*}$ & $0.62(0.30 ; 1.26)^{*}$ \\
\hline
\end{tabular}

*: reliable difference of the indices as compared to the comparison group $(P<0.05)$. 
Table 2. Dynamics of cytokine indexes in blood serum of children with FDPTB with isolated tuberculosis in the course of $A M B T$ Me $\left[Q_{25} ; Q_{75}\right]$

\begin{tabular}{lllll}
\hline Cytokines, $\mathrm{pg} / \mathrm{ml}$ & Comparison group $(\mathrm{n}=\mathbf{3 0})$ & Main group $(\mathrm{n}=11)$ & \\
\cline { 3 - 5 } & & At the beginning of IPh AMBT & On the IPh AMBT completion & On the MPh AMBT completion \\
\hline IL-6 & $1.58(1.45 ; 1.78)$ & $0.08(0.04 ; 0.30)^{*}$ & $0.16(0.06 ; 0.24)^{*}$ & $0.08(0.04 ; 1.60)$ \\
IL-4 & $1.74(1.54 ; 1.94)$ & $0.68(0.56 ; 0.74)^{*}$ & $0.68(0.56 ; 0.76)^{*}$ & $0.64(0.52 ; 0.68)^{*}$ \\
IL-2 & $0.30(0.24 ; 0.35)$ & $1.02(0.56 ; 1.68)^{*}$ & $1.10(0.76 ; 1.34)^{*}$ & $1.12(0.48 ; 1.40)^{*}$ \\
IL-10 & $3.47(2.88 ; 3.68)$ & $1.80(1.12 ; 4.22)$ & $0.86(0.64 ; 1.96)^{*}$ & $0.82(0.52 ; 2.78)$ \\
\hline
\end{tabular}

*: reliable difference of the indices as compared to the comparison group $(P<0.05)$.

of the comparison group during the entire course of AMBT: at the beginning of IPh AMBT $(1.40(0.46 ; 2.85)$ relative units as compared with $0.08(0.06 ; 0.11)$ relative units $)$ with a tendency to a slight decrease on the IPh AMBT completion $(1.00(0.61 ; 1.90)$ relative units as compared with 0.08 $(0.06 ; 0.11)$ relative units; $(P<0.05)$, as well as on the MPh completion $(1.16(0.62 ; 2.06)$ relative units as compared with $0.08(0.06 ; 0.11)$ relative units; $(P<0.05)$. The level of IL-6/ $\mathrm{IL}-10$ index remained stably 3 times lower during the entire course of AMBT as compared to the comparison group ( 0.17 $(0.03 ; 0.54)$ relative units, $0.18(0.12 ; 0.53)$ relative units and $0.14(0.06 ; 0.42)$ relative units $(\mathrm{P}<0.05)$ as compared with $0.48(0.39 ; 0.54)$ relative units).

Thus, in children with FDPTB with disseminated tuberculosis during the entire course of AMBT significantly high levels of the pro-inflammatory cytokine IL-2 testified a high activity of Th1-type cellular immune response. And reliably stably decreased levels of anti-inflammatory cytokines IL-4 and IL-10 indicated insufficiency of anti-inflammatory response during the entire course of AMBT. Calculation of cytokine indexes (and namely the ratio IL-2/IL-10) conformed that there was a disbalance between pro-inflammatory cytokines and anti-inflammatory cytokines towards pro-inflammatory cytokines with predominance of Th1-type cellular immune response which lasted during the entire course of antimycobacterial therapy and tended to decline on its completion.

In the course of treatment for children with isolated FDPTB (Table 2) there were also a reliably high level of pro-inflammatory cytokine IL-2 as compared to the comparison group during the entire course of AMBT: $1.02(0.56$; 1.68) $\mathrm{pg} / \mathrm{ml}, 1.10(0.76 ; 1.34) \mathrm{pg} / \mathrm{ml}$ and $1.12(0.48 ; 1.40)$ $\mathrm{pg} / \mathrm{ml}$ as compared with $0.30(0.24 ; 0.35) \mathrm{pg} / \mathrm{ml}(\mathrm{P}<0.05)$. The level of anti-inflammatory cytokine IL-4 was also reliably stably decreased during the entire course of AMBT - 2.5 times lower $(0.68(0.56 ; 0.74) \mathrm{pg} / \mathrm{ml}, 0.68(0.56 ; 0.76) \mathrm{pg} /$ $\mathrm{ml}$ and $0.64(0.52 ; 0.68) \mathrm{pg} / \mathrm{ml}$ compared to $1.74(1.54$; 1.94) $\mathrm{pg} / \mathrm{ml} ; \mathrm{P}<0.05)$. The level of IL-10 in children at the beginning of IPh AMBT was almost 2 times lower than the corresponding level of healthy persons $(1.80(1.12 ; 4.22)$ $\mathrm{pg} / \mathrm{ml}$ compared to $3.47(2.88 ; 3.68) \mathrm{pg} / \mathrm{ml})$. But against the background of ongoing AMBT it was decreased twofold on the IPhAMBT completion $(0,86(0,64 ; 1,96))$ and that was reliably 4 times lower as compared to the comparison group. This level of IL-10 was also remained on the basic course of AMBT completion $(0.82(0.52 ; 2.78))$. The level of IL-6 was also reliably low during the entire course of treatment.

Data of cytokine indexes in children with isolated FDPTB identification also revealed a pronounced disbalance between pro-inflammatory and anti-inflammatory cytokines towards pro-inflammatory cytokines with predominance of Th1-type cellular immune response and this disbalance was remained during the entire course of AMBT

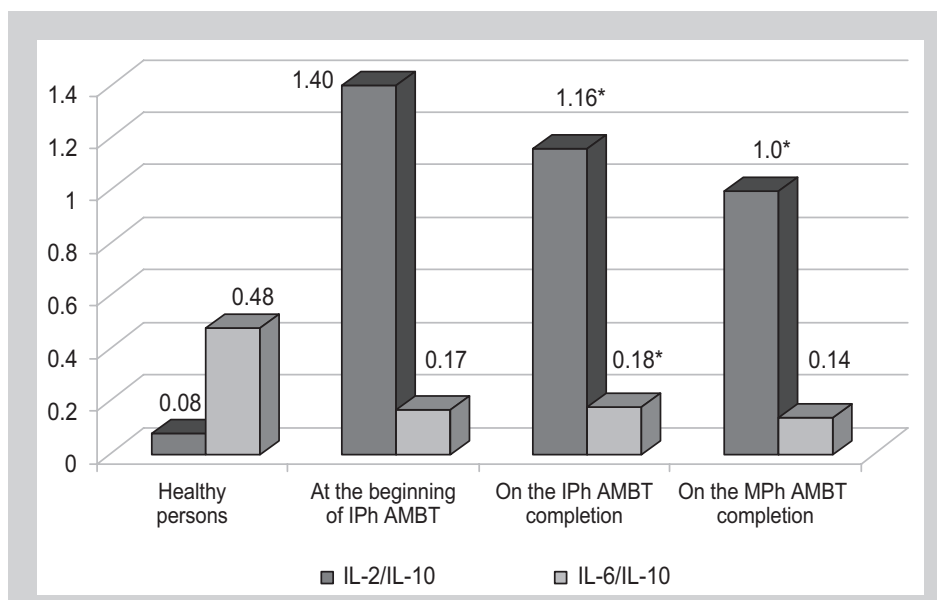

Fig. 1. Cytokine indexes in blood serum of children with disseminated FDPTB in the course of AMBT, relative units.

*: reliable difference of the indices as compared to the comparison group $(P<0.05)$

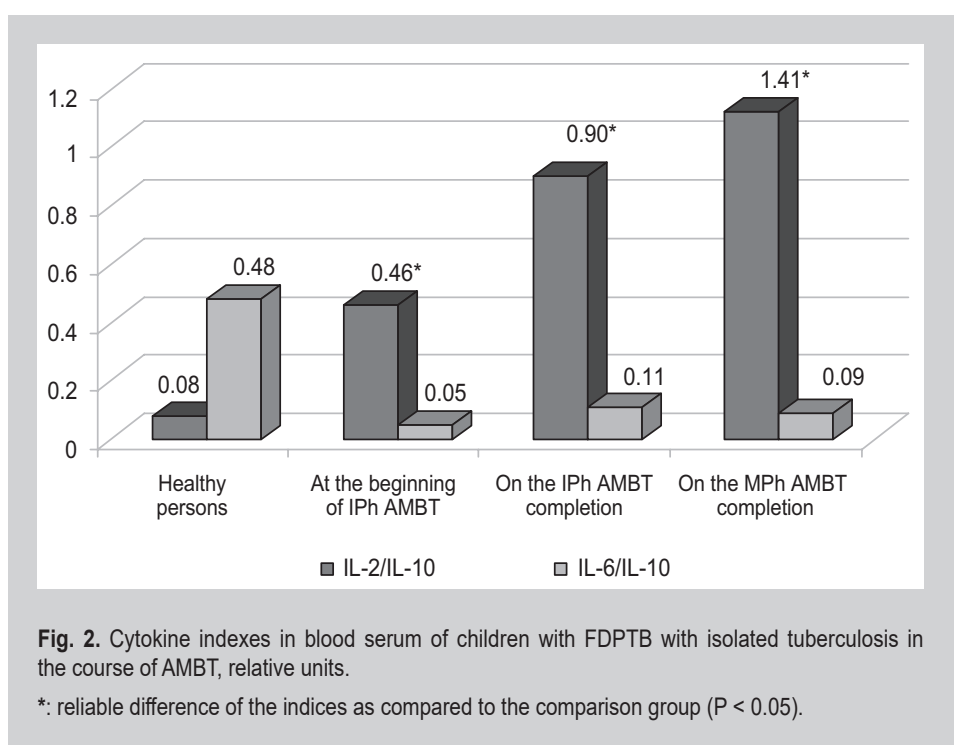

(Fig. 2). But in contrast to children of the 1 group a gradual reliable growth of IL-2/LL-10 index was determined through the reduction of IL-10 $(0.46(0.34 ; 0.74)$ relative units, 0.90 $(0.71 ; 2.12)$ relative units and $1.12(0.16 ; 2.35)$ relative units as compared with $0.48(0.39 ; 0.54)$ relative units; $P<0.05)$. The level of IL-6/IL-10 index also was stably low during the entire course of AMBT and did not significantly differ from the corresponding index of healthy children $(0.05(0.01$; $0.30)$ relative units, $0.11(0.03 ; 0.57)$ relative units and 0.09 $(0.05 ; 0.27)$ relative units $(P<0.05)$ as compared with 0.48 $(0.39 ; 0.54)$ relative units). 
It has been determined that cytokine indexes (IL-2, 4, $6,10)$ did not differ significantly during various phases of treatment. Also no difference has been found between cytokine indexes depending on the specific process prevalence.

So, in children with isolated FDPTB as well as with disseminated specific process the obtained data indicated that in the course AMBT a high activity of Th1-type cellular immune response was remained against the background of extremely decreased activity of Th2-type cellular immune response with a pronounced disbalance between pro-inflammatory and anti-inflammatory cytokines towards pro-inflammatory cytokines.

At the beginning of treatment lung destructions were diagnosed in 7 children of the 1 group (41.2\%) and against the background of AMBT and determined changes of the cytokine profile they healed in 6 children $(35.3 \%)$ on the average after $(4.17 \pm 0.41)$ months. Bacterioexcretion was determined in 11 persons (64.7\%) and it stopped in all patients on the average after $(2.0 \pm 0.47)$ months. At the same time duration of in-patient treatment was $(9.1 \pm 0.97)$ and in 3 patients (17.6\%) multidrug-resistant tuberculosis was diagnosed and 1 patient of them (5.9\%) had a widened resistance of Mycobacterium tuberculosis.

Among children with isolated FDPTB no destructive processes were registered and bacterioexcretion was determined in 2 persons $(18.2 \%)$ and it stopped in all patients on the average after a month. But duration of the in-patient treatment course was $(10.5 \pm 1.49)$ months.

\section{Conclusions}

1. Children with first diagnosed pulmonary tuberculosis (regardless of the specific process prevalence) had a high activity of Th1-type cellular immune response against the background of an extremely decreased activity of Th2type cellular immune response throughout the entire course of antimycobacterial therapy. At the same time all children had a pronounced disbalance between pro-inflammatory and anti-inflammatory cytokines towards pro-inflammatory ones on completion of the treatment basic course. These changes may contribute to the specific process progression as well as early recurrences of the disease.

2. Even though that in the course of AMBT in children with bacterioexcretion this process stopped, average duration of in-patient treatment was 9-10 months and that was 3 months longer than standard treatment of patients with FDPTB. The warning sign is also that among children with disseminated tuberculosis there were 3 cases $(17.6 \%)$ of multidrug-resistant tuberculosis in the course of treatment and in case with 1 child (5.9\%) lung destruction was persisted on the treatment completion.

Prospects of further researches. Development of pathogenetic correction of the revealed abnormalities in cytokine profiles of children with FDPTB regardless of the specific process prevalence which will promote effectiveness of AMBT and reduction of in-patient treatment period.
[2] Bilogortseva, O. I., Pobedonna, G. P., Rekalova, O. M., Dotsenko, Ya. I., Koposova, I. V., \& Firsova, A. P. (2015). Osoblyvosti stanu imunitetu u ditei, khvorykh na vpershe diahnostovanyi tuberkuloz [Peculiarities of immune status in children with newly diagnosed tuberculosis]. Ukrainskyi pulmonolohichnyi zhurnal, 3, 20-24. [in Ukrainian].

[3] Shalmin, O. S., Raznatovska, O. M., Abramov, A. V., \& Zhernova, H. O. (2011). Osoblyvosti tsytokinovoho profiliu u khvorykh na khimiorezystentnyi tuberkuloz lehen [Specificity of the cytokine profil in hvorih on chemorioresistent tuberculosis]. Ukrainskyj zhurnal klininichnoi ta laboratrnoi medytsyny, 2, 68-71. [in Ukrainian].

[4] Mezentseva, M. V., Stakhanov, V. A., Zakharova, M. V., Zotova, I. F., Tregubova, M. I., \& Shapoval, I. M. (2011). Citokiny kak markery razvitiya infil'trativnogo tuberkuleza legkikh [Cytokines as markers of the infiltrative pulmonary tuberculosis development]. Infekciya i immunitet, 1(4), 367-372. [in Russian].

[5] Piskur, Z. I., Mykolyshyn, L. I., Platonova, I. L., \& Lapovets, L. Ye. (2017). Osoblyvosti tsytokinovoho spektra IL-1 $\beta$, IL-2, IL-10 i TNF- $\alpha$ u ditei, khvorykh na tuberkuloz [Peculiarities of cytokine spectrum IL-1 $\beta$, IL-2, IL-10 and TNF- $\alpha$ in children with tuberculosis]. Tuberkuloz, lehenevi hvoroby, VIL-infektsiia, 1(28), 42-47. [in Ukrainian].

[6] Vivchar, I. S., \& Zaleckij, N. P. (2013). Korrelyacionnye svyazi pokazatelej immunnogo i citokinovogo statusa u detej i podrostkov, bol'nykh tuberkulezom legkikh. [Correlation of indicators immune and cytokine status in children and adolescents with pulmonary tuberculosis]. Sovremennye problemy nauki i obrazovaniya, 6. [in Russian].

[7] Martinez, A. N., Mehra, S. \& Kaushal, D. (2013). Role of interleukin 6 in innate immunity to Mycobacterium tuberculosis infection. J Infect Dis, 207(8), 1253-61. doi: 10.1093/infdis/jit037.

[8] Redford, P. S., Murray, P. J., \& Garra, A. O. (2011). The role of IL-10 in immune regulation during M. tuberculosis infection. Mucosal Immunology, 4(3), 261-270. doi:10.1038/mi.2011.7.

[9] Peresi, E., Silva, S. M., Calvi, S. A., \& Marcondes-Machado, J. (2008). Cytokines and acute phase serum proteins as markers of inflammatory regression during the treatment of pulmonary tuberculosis. Jornal Brasileiro de Pneumologia, 34(11), 942-949.

\section{Відомості про авторів:}

Разнатовська О. М., А-р мед. наук, Аоцент, професор каф. фтизіатрії і пульмонології, Запорізький Аержавний медичний університет, Україна.

Мирончук Ю. В., викладач-стажист каф. фтизіатрії і пульмонології, Запорізький державний медичний університет, Україна.

\section{Сведения об авторах:}

Разнатовская Е. Н., А-р меА. наук, Аоцент, профессор каф. фтизиатрии и пульмонологии, Запорожский государственный медицинский университет, Украина. Мирончук Ю. В., преподаватель-стажер каф. фтизиатрии и пульмонологии, Запорожский государственный меАицинский университет, Украина.

\section{Information about authors:}

Raznatovska O. M., MD, PhD, DSc, Professor, Associate Professor, Department of Phthisiology and Pulmonology, Zaporizhzhia State Medical University, Ukraine.

Mironchuk Yu. V., MD, Trainee Teacher, Department of Phthisiology and Pulmonology, Zaporizhzhia State Medical University, Ukraine.

Conflicts of Interest: authors have no conflict of interest to declare. Конфмікт інтересів: віАсутній.

Надійшла Ао редакції / Received: 08.11.2017

Після Аоопрацювання / Revised: 14.11.2017

Прийнято Ао Аруку / Accepted: 23.11.2017

\section{References}

[1] Belogortseva, O. I. (2014). Epidemiolohichna sytuatsiia shchodo tuberkulozu u ditei $v$ Ukraini ta shliakhy udoskonalennia nadannia protytuberkuloznoi dopomohy ditiam [The epidemiological situation of tuberculosis in children in Ukraine and ways to improve TB care to children]. Sovremennaya pediatriya, 5, 22-26. [in Ukrainian]. 